\title{
Transferability of Barley Retrotransposons (Sukkula and Nikita) to Investigate Genetic Structure of Pimpinella anisum L.
}

\author{
Arpa Retrotranspozonlarının (Sukkula ve Nikita) Pimpinella Anisum L.'nin Genetik Yapısını \\ İncelemeye Aktarılabilirliği
}

\author{
Sevgi MARAKLI ${ }^{1}$ (i) \\ ${ }^{1}$ Amasya University, Faculty of Arts and Sciences, Department of Biology, 05100, Amasya, Turkey
}

\begin{abstract}
Transferability of barley retrotransposons (Nikita and Sukkula) were examined in Pimpinella anisum L. seeds by using a retrotransposon-based molecular marker: IRAP (inter-retrotransposon amplified polymorphism). Furthermore, transposons' sequences identified in medically important plants were obtained form NCBI, and multiple alignment analyses were performed to investigate the evolutionary relationships. These two retrotransposons were identified in Pimpinella anisum L., showing homomorphic band profiles. In addition, limited similar sequences were detected as a result of clustal analyses. Till date, no study about retrotransposons evaluation using IRAP as molecular marker has been published in aniseed. Our results are expected to contribute a new perspective for genome architect of medically important plants in addition to aniseed.
\end{abstract}

Keywords: Aniseed, IRAP, Medical Plants, Mobile Genetic Elements

$\ddot{O} \mathbf{z}$

Arpa retrotranspozonlarının (Nikita ve Sukkula) aktarılabilirliği, retrotranspozon temelli bir moleküler markır olan IRAP (retrotranspozon-arası çoğaltılmış polimorfizm) yöntemi kullanılarak Pimpinella anisum L. tohumlarında incelendi. Ayrıca, tıbbi olarak önemli bitkilerde tanımlanan transpozonların dizileri, NCBI'dan elde edildi ve evrimsel ilişkileri araştırmak için çoklu hizalama analizleri yapıldı. Pimpinella anisum L. bitkisinde tanımlanan bu iki retrotranspozon homomorfik bant profili gösterdi. Bununla birlikte, çoklu hizalama analizleri sonucunda sınırlı sayıda benzer diziler tespit edildi. Bugüne kadar, anasonda IRAP gibi bir moleküler markır kullanılarak retrotranspozon değerlendirmesi yapan bir çalışma yayınlanmamıştır. Sonuçlarımızın, anason ile birlikte tıbbi açıdan önemli bitkilerin genom yapısının anlaşılması için yeni bir bakış açısına katkıda bulunması bekleniyor.

Anahtar Kelimeler: Anason, IRAP, Tıbbi Bitkiler, Hareketli Genetik Elementler

\section{INTRODUCTION}

Pimpinella anisum L. (aniseed) belonging to Apiaceae family is an annual herb with white flowers and small green/yellow seeds, cultivating Europe, Asian countries and Latin America in addition to many other warm regions of the world [1, 2]. The seeds have been commonly used for folk medicine, pharmacy, food industry and even as a spice [3]. There are many reports about antibacterial [4], anti-oxidative [5], antitoxicity [6] and also anticancer [7] effects of essential oils in aniseed. On the other hand, there is still some concern related to the safety and efficiency. DNA technology/molecular markers are used to prevent these problems. For this purpose, there are many studies related to DNA markers for identification of herbal medicinal species and their adulterants, investigation of genetic changes as a result of biotic/abiotic stress DNA fingerprinting among species and different tissues of the same plant, and evolutionary relationships [8]. One class of these markers is developed on the basis of retrotransposon sequences. Retrotransposons are mobile genetic elements, moving via an 
RNA intermediate in genome. Retrotransposon-based molecular markers are codominant, ubiquitous, highly abundant and randomly distributed with high copy numbers in plant genomes [9-12]. Inter-retrotransposon amplified polymorphism (IRAP) is one of the retrotransposon-based molecular markers, amplifying genomic distance between two long terminal repeats (LTRs) found in both two ends of the retrotransposon. In this method, polymorphisms can be calculated by the presence or absence of the PCR product [13]. Sequences of identical LTR retrotransposons indicate the relatedness among species [14]. Therefore, LTR primers designed according to a species can be used to amplify DNA of others. As a result, IRAP gives very valuable information related to the genomes of different species $[15,16]$.

The major objective of this study was to detect Nikita and Sukkula retrotransposons, identified in barley [17], in aniseed genome by using IRAP technique. Moreover, different transposons described in medically important plant families were also investigated to evaluate evolutionary relationships.

\section{MATERIALS AND METHODS}

\subsection{Genomic DNA Isolation and IRAP-PCR}

Genomic DNAs were isolated from seven Pimpinella anisum L. seeds according to Kidwell and Osborn [18] with minor modifications. The quality and the quantity of gDNA was controlled on $1 \%$ agarose gel and a spectrophotometer, respectively. IRAP-PCR was performed with Nikita and Sukkula specific primers (5'ACCCCTCTAGGCGACATCC3' for Nikita and 3'GGAACGTCGGCATCGGGCTG5' for Sukkula) [19]. Amplification reactions were carried out in $20 \mu 1$ reaction mixtures, including 9.8 $\mu 1$ of nuclease-free $\mathrm{dH}_{2} \mathrm{O}, 2 \mu \mathrm{l}$ of reaction buffer (K1071, Fermentas), $2 \mu \mathrm{l}$ of $\mathrm{MgCl}_{2}(2.5 \mathrm{mM}), 0.6 \mu \mathrm{dNTP}$ mixture $(0.3 \mathrm{mM}), 2 \mu \mathrm{l}$ of primer $(1 \mu \mathrm{M} / \mu \mathrm{L}), 3 \mu \mathrm{l}$ of $20 \mathrm{ng} / \mu \mathrm{l}$ template genomic DNA ( $3 \mathrm{ng} / \mu \mathrm{l})$ and $0.6 \mu \mathrm{l}$ of enzyme $(0.15 \mathrm{U} /$ $\mu 1)$. The values given in parenthesis indicated the final concentrations of PCR components. The amplification conditions were set up as an initial denaturation step at $94^{\circ} \mathrm{C}$ for $3 \mathrm{~min}$ followed by 30 cycles of $94^{\circ} \mathrm{C}$ for $30 \mathrm{~s}$, annealing for $30 \mathrm{~s}\left(50^{\circ} \mathrm{C}\right.$ for Nikita and $56^{\circ} \mathrm{C}$ for Sukkula) and $72^{\circ} \mathrm{C}$ for $3 \mathrm{~min}$. The reaction was completed by a final extension step at $72^{\circ} \mathrm{C}$ for $10 \mathrm{~min}$. All the experiments were performed with independent biological replicates (seven seeds). PCR products were resolved on $1 \%$ agarose gel in $1 \mathrm{X}$ TrisBorate-EDTA at $120 \mathrm{~V}$ for $120 \mathrm{~min}$ and photographed on a UV transilluminator. Molecular weight marker (GeneRuler $^{\mathrm{TM}} 1$ kb DNA Ladder, SM0312, Fermentas) was also used to determine the size of amplicons. After agarose gel electrophoresis, gels were photographed on a UV transilluminator. Band profiles among samples for Nikita and Sukkula were examined.

\subsection{Multiple Alignment Analyses}

Different transposons sequences belonging to the seven medically important plant families were obtained from NCBI (The National Center for Biotechnology Information - www.ncbi.nlm.nih.gov) (Table 1). Then, multiple alignment analyses were performed with Clustal Omega (http:// www.ebi.ac.uk/Tools/msa/clustalo) and limited similar sequences were obtained. Therefore, it was not enough to construct a phylogenetic tree.

Table 1. Analysed plants and transposons' sequences

\begin{tabular}{|c|c|c|c|}
\hline $\begin{array}{l}\text { Accession } \\
\text { number }\end{array}$ & Family Name & Plant name & Transposon \\
\hline AY585677.3 & \multirow{4}{*}{ Alliaceae } & Allium cepa & PINK \\
\hline KM434203.1 & & Allium cepa & AcCACTA1 \\
\hline KM434202.1 & & Allium cepa & AcCOPIA1 \\
\hline EF192476.2 & & Allium cepa & $h A T 1$ \\
\hline DQ250807.1 & \multirow{4}{*}{ Apiceae } & Daucus carota & $\begin{array}{l}\text { PIF-like DcMas- } \\
\text { ter-1 }\end{array}$ \\
\hline DQ250806.1 & & Daucus carota & $\begin{array}{l}\text { PIF-like DcMas- } \\
\text { ter-a }\end{array}$ \\
\hline AB071213.1 & & Daucus carota & $T d c B 2-2$ \\
\hline AB001569.1 & & Daucus carota & $T d c 1$ \\
\hline DQ229838.1 & Asteraceae & $\begin{array}{l}\text { Helianthus an- } \\
\text { nuus cultivar } \\
\text { R112 }\end{array}$ & $\begin{array}{l}\text { Gypsy-like retrot- } \\
\text { ransposon }\end{array}$ \\
\hline D37795.1 & \multirow{2}{*}{$\begin{array}{l}\text { Convolvula- } \\
\text { ceae }\end{array}$} & Ipomoea nil & Tpn1 \\
\hline AB073921.1 & & Ipomoea nil & Tpn 8 \\
\hline EU009625.1 & $\begin{array}{l}\text { Cucurbita- } \\
\text { ceae }\end{array}$ & $\begin{array}{l}\text { Citrullus lanatus } \\
\text { var. lanatus }\end{array}$ & Cila-1 \\
\hline AM040263.2 & Rutaceae & Citrus sinensis & CIRE1.1 \\
\hline AF279585.2 & \multirow{4}{*}{ Solanaceae } & $\begin{array}{l}\text { Lycopersicon chi- } \\
\text { lense }\end{array}$ & TLC1.1 \\
\hline AF228701.1 & & $\begin{array}{l}\text { Lycopersicon pe- } \\
\text { ruvianum }\end{array}$ & Retrolyc1-1 \\
\hline X13777.1 & & $\begin{array}{l}\text { Nicotiana taba- } \\
\text { cum }\end{array}$ & Tnt 1-94 \\
\hline U91987.1 & & $\begin{array}{l}\text { Solanum tube- } \\
\text { rosum }\end{array}$ & Potten 1 \\
\hline
\end{tabular}

\section{RESULTS}

\subsection{Nikita and Sukkula were Identified in Aniseed}

Nikita IRAP-PCR analyses of seven Pimpinella anisum L. seeds were demonstrated homomorphic band profiles, 
ranging from $250 \mathrm{bp}$ to $6000 \mathrm{bp}$. There was no polymorphic band among samples (Figure 1).

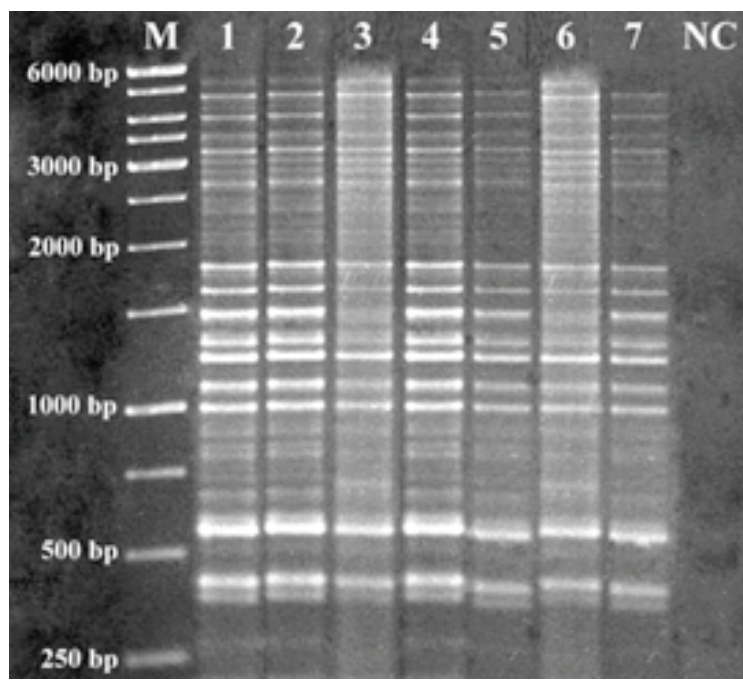

Figure 1. IRAP-PCR results of Nikita. M, marker; NC, negative control. Numbers shows seven different seeds of Pimpinella anisum $\mathrm{L}$.

In addition to Nikita, another retrotransposon, Sukkula also showed only homomorphic bands among samples (Figure 2).

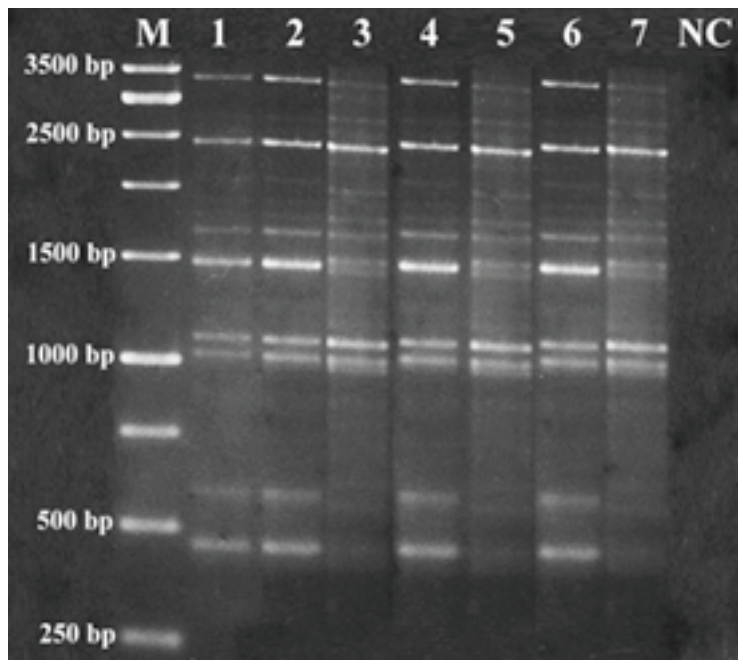

Figure 2. IRAP-PCR results of Sukkula. M, marker; NC, negative control. Numbers shows seven different seeds of Pimpinella anisum $\mathrm{L}$.

Sukkula band profiles were different when compared to Nikita, indicating fewer bands with the length between 500 and 3500 bp. Furthermore, some bands with the same base pairs were observed in both Nikita and Sukkula (Figure 3).

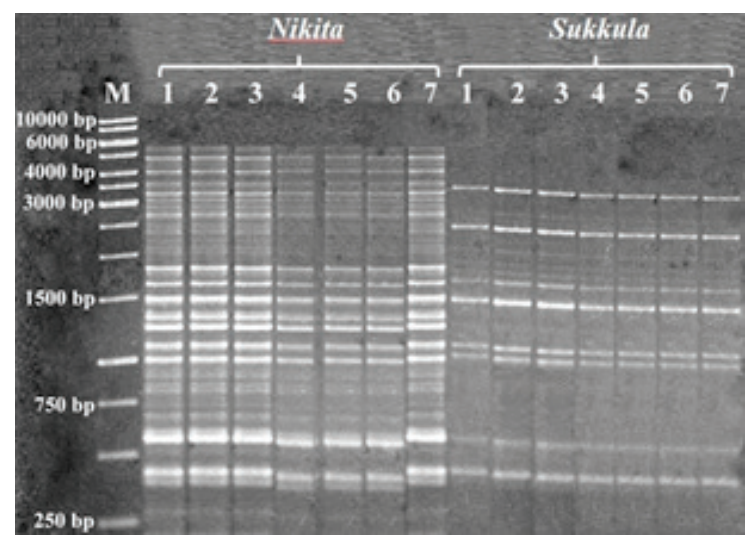

Figure 3. IRAP-PCR results of Nikita and Sukkula. M, marker; $\mathrm{NC}$, negative control. Numbers shows seven different seeds of Pimpinella anisum L.

\subsection{Clustal Analyses Indicated Very Few Similar Sequences}

We observed limited similarity (a) similar transposon sequences belonging to the same plant species (such as PIFlike DcMaster-1 and PIF-like DcMaster-a in Daucus carota), (b) different transposon sequences found in same plant species (such as Alliaceae family), in addition to different transposons's sequences in different families (Figure. 4).

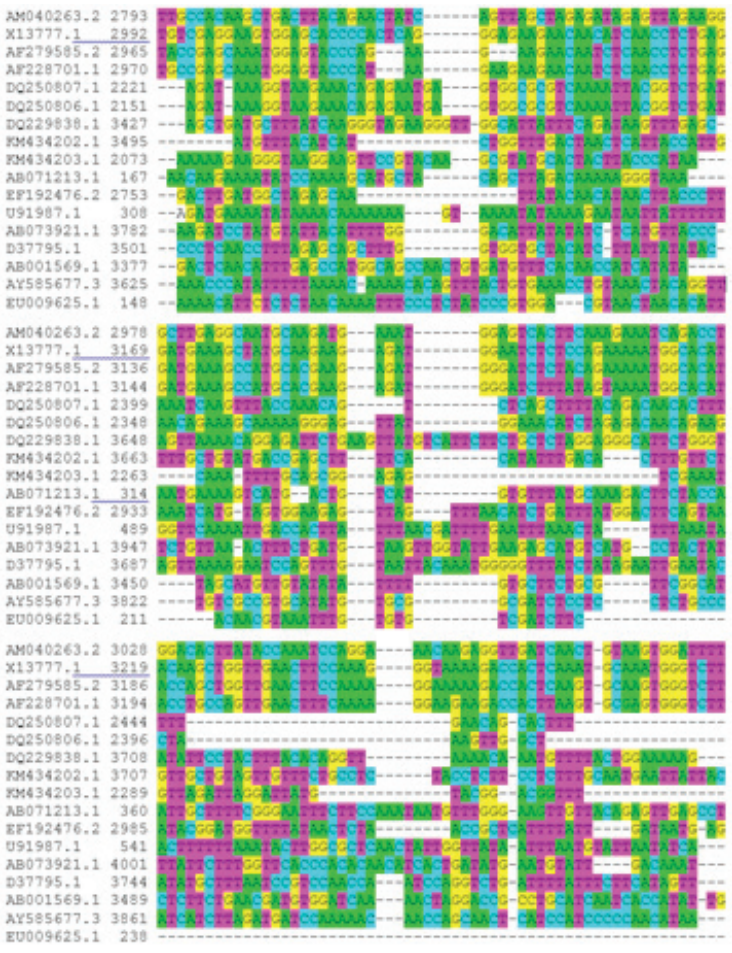

Figure 4. Alignment of the deduced sequences obtained from seven families. Every four nucleotides indicated in different colours 


\section{DISCUSSION}

There are many reports related to the essential oils of aniseed characterised by antispasmodic, antioxidant, antimicrobial, insecticidal, and antifungal effects [20]. On the other hand, there is no study to investigate retrotransposon movements in aniseed. In this study, barley-specific retrotransposons (Nikita and Sukkula) were detected in aniseed genome for the first time, founding homomorphic band profiles.

IRAP markers were used for analysing polymorphism in different populations. One of them was performed by Boronnikova and Kalendar [21], observing 125 polymorphic IRAP markers in Adonis vernalis populations. Moreover, Soorni et al. [22] investigated the same retrotransposons' movements in another medical plant, Leonurus cardiaca L., reporting $\geq 80 \%$ polymorphism among samples. Nikita retrotransposon movements in Avena species also analysed by Tomás et al. [23]. Different obtaining results could be depended on plant species, different transposons and environmental conditions. Furthermore, a specific retrotransposon could be found in different plant species even humans with different polymorphism ratios $[15,16]$.

In addition to retrotransposons, many DNA barcodes such as $r b c L, m a t K, t r n H-p s b A$ and ITS has been widely studied to evaluate biodiversity and conservation. Furthermore, they are also a reliable tool for species identification in addition to safety and quality control [24]. Especially, ITS2 DNA barcode is commonly used for identification of medicinal plants $[25,26]$. In addition, nuclear ribosomal DNA (nrDNA) ITS region is also a popular marker, comprising the database for Apiaceae subfamily Apioideae [27]. Wang et al. [28] studied with nrDNA ITS and cpDNA intron sequence data to understand evolutionary relations between Pimpinella and related genera (Apiaceae). Furthermore, ITS sequences of Pimpinella pruatjan were investigated to identify the relationships among other Pimpinella species [29].

Other molecular marker techniques have been also performed to assess genetic diversity. Wang et al. [30] investigate the genetic diversity of Rheum officinale by using ISSR. They concluded that diversity was high at the species level, whereas low at the population level. The genetic diversity of Trigonella foenum-graecum was also investigated using RAPD and ISSR markers in addition to nrDNA and ITS barcodes [31, 32]. Moreover, similar to our study, Kumar et al. [33] investigated Daucus carota microsatellite markers in another species, Cuminum cyminum.

Analysing of suitable DNA barcodes for every species play an important role in diversity analyses [8]. Transposable elements are source of genetic and epigenetic variabilities and so important drivers of evolution [34]. LTR retrotransposon transferability among species could be as a result of analogous to virus capsid [35]. Sun et al. [36] studied with the transferability of pear IRAP to apples and other Rosaceae species. Different from our results, they reported that polymorphism was very high, ranging from 87.5 to $100 \%$. The transferability of DNA markers depends on genome similarity, showing genome collinearity and evolutionary relationships species [37]. Therefore, molecular markers have been commonly used for genetic reports because of interspecific and intergeneric transferability [38]. To our knowledge, this is the first report about retrotransposon-based marker, IRAP, for identifying Nikita and Sukkula in aniseed genome. The study revealed that both two retrotransposons were found in aniseed, indicating homomorphic band profiles. Retrotransposons' markers investigations have commonly used for knowledge of diversity. Therefore, our findings might contribute valuable information related to genomes of medical plants.

\section{REFERENCES}

[1] Gülçın, İ., Oktay, M., Kıreçcı, E., \& Küfrevıoğlu, Ö.İ., (2003). Screening of Antioxidant and Antimicrobial Activities of Anise (Pimpinella anisum L.) Seed Extracts. Food Chemistry, 83(3), 371-382.

[2] Rodrigues, V.M., Rosa, P.T., Marques, M.O., Petenate, A.J., \& Meireles, M.A.A., (2003). Supercritical Extraction of Essential Oil From Aniseed (Pimpinella anisum L) Using $\mathrm{CO}_{2}$ : Solubility, Kinetics, and Composition Data. Journal of Agricultural and Food Chemistry, 51(6), 1518-1523.

[3] Samojlik, I., Mijatović, V., Petković, S., Škrbić, B., \& Božin, B., (2012). The Influence of Essential Oil of Aniseed (Pimpinella anisum, L.) on Drug Effects on the Central Nervous System. Fitoterapia, 83(8), 1466-1473.

[4] Ibrahim, M.K., Mattar, Z.A., Abdel-Khalek, H.H., \& Azzam, Y.M., (2017). Evaluation of Antibacterial Efficacy of Anise Wastes Against Some Multidrug Resistant Bacterial Isolates. Journal of Radiation Research and Applied Sciences, 10(1), 34-43.

[5] Koriem, K.M., Arbid, M.S., \& El-Gendy, N.F., (2016). The Protective Role of Anise Oil in Oxidative Stress and Genotoxicity Produced In Favism. Journal of Dietary Supplements, 13(5), 505-521.

[6] Jamshidzadeh, A., Heidari, R., Razmjou, M., Karimi, F., Moein, M.R., Farshad, O., Akbarizadeh, A.R. \& Shayesteh, M. R. H., (2015). An in vivo and in vitro Investigation on Hepatoprotective Effects of Pimpinella anisum Seed Essential Oil and Extracts Against Carbon Tetrachloride-Induced Toxicity. Iranian Journal of Basic Medical Sciences, 18(2), 205-211.

[7] Asadi, M.H., \& Rahamooz-Haghighi, S., (2016). Anti-Proliferative Effect of the Extracts and Essential Oil of Pimpinella 
anisum on Gastric Cancer Cells. Journal of HerbMed Pharmacology, 5(4), 157-161.

[8] Li, L., Josef, B.A., Liu, B., Zheng, S., Huang, L., \& Chen, S., (2017). Three-Dimensional Evaluation on Ecotypic Diversity of Traditional Chinese Medicine: A Case Study of Artemisia annua L. Frontiers in Plant Science, 8, 1225.

[9] Wicker, T., Sabot, F., Hua-Van, A., Bennetzen, J.L., Capy, P., Chalhoub, B., Flavell, A., Leroy, P., Morgante, M., Panaud, O., Paux, E., SanMiguel, P., \& Paux, E., (2007). A Unified Classification System for Eukaryotic Transposable Elements. Nature Reviews Genetics, 8(12), 973-982.

[10] Schulman, A.H., Flavell, A.J., Paux, E., Ellis, T.H.N., (2012). The application of LTR retrotransposons as molecular markers in plants. In: Bigot, Y. (ed.), Mobile Genetic Elements: Protocols and Genomic Applications. Humana Press, 115153.

[11] Gozukirmizi, N., Temel, A., Marakli, S., Yilmaz, S., (2016). Transposon Activity in Plant Genomes. In: Hakeem, H.R., Tombuloglu, H., Tombuloglu, G. (eds.), Plant Omics: Trends and Applications. Springer-Verlag, Springer International Publishing Switzerland, 83-108.

[12] Gozukirmizi, N., Yilmaz, S., Marakli, S., Temel, A., (2015). Retrotransposon-Based Molecular Markers; Tools for Variation Analyses in plants. In: Taski-Adjukovic, K. (ed.), Applications of Molecular Markers in Plant Genome Analysis and Breeding. Research Signpost, Kerala, 19-45.

[13] Kalendar, R., (2011). The Use of Retrotransposon-Based Molecular Markers to Analyze Genetic Diversity. Ratarstvo $i$ Povrtarstvo, 48, 261-274.

[14] Kalendar, R., Tanskanen, J., Chang, W., Antonius, K., Sela, H., Peleg, O., \& Schulman, A.H., (2008). Cassandra Retrotransposons Carry Independently Transcribed 5S RNA. Proceedings of the National Academy of Sciences, 105(15), 5833-5838.

[15] Cakmak, B., Marakli, S., \& Gozukirmizi, N., (2015). SIRE1 Retrotransposons in Barley (Hordeum vulgare L.). Russian Journal of Genetics, 51(7), 661-672.

[16] Cakmak, B., Marakli, S., \& Gozukirmizi, N., (2017). Sukkula Retrotransposon Movements in the Human Genome. Biotechnology \& Biotechnological Equipment, 31(4), 756-760.

[17] Shirasu, K., Schulman, A.H., Lahaye, T., \& Schulze-Lefert, P., (2000). A Contiguous 66-kb Barley DNA Sequence Provides Evidence for Reversible Genome Expansion. Genome Research, 10(7), 908-915.

[18] Kidwell, K.K., Osborn, T.C., (1992). Simple Plant DNA Isolation Procedures, In: Beckmann, J.S., Osborn, T.C. (eds.) Plant Genomes: Methods for Genetic and Physical Mapping. Kluwer Academic Publishers, Dordrecht, The Netherlands, $1-13$.

[19] Leigh, F., Kalendar, R., Lea, V., Lee, D., Donini, P., \& Schulman, A. H., (2003). Comparison of the Utility of Barley Retrotransposon Families for Genetic Analysis by
Molecular Marker Techniques. Molecular Genetics and Genomics, 269(4), 464-474.

[20] Shojaii, A., \& Abdollahi Fard, M., (2012). Review of Pharmacological Properties and Chemical Constituents of Pimpinella anisum. ISRN pharmaceutics,

[21] Boronnikova, S.V., \& Kalendar, R. N., (2010). Using IRAP Markers for Analysis of Genetic Variability in Populations of Resource and Rare Species of Plants. Russian Journal of Genetics, 46(1), 36-42.

[22] Soorni, A., Nazeri, V., Fattahi, R., \& Khadivi-Khub, A., (2013). DNA Fingerprinting of Leonurus cardiaca L. Germplasm in Iran Using Amplified Fragment Length Polymorphism and Inter-Retrotransposon Amplified Polymorphism. Biochemical Systematics and Ecology, 50, 438-447.

[23] Tomás, D., Rodrigues, J., Varela, A., Veloso, M.M., Viegas, W., \& Silva, M., (2016). Use of Repetitive Sequences for Molecular and Cytogenetic Characterization of Avena species From Portugal. International Journal of Molecular Sciences, 17(2), 203.

[24] Li, M., Cao, H., But, P.P.H., \& Shaw, P.C., (2011). Identification of Herbal Medicinal Materials Using DNA Barcodes. Journal of Systematics and Evolution, 49(3), 271-283.

[25] Chen, S., Yao, H., Han, J., Liu, C., Song, J., Shi, L., Zhu, Y. Ma, X., Gao, T., Pang, X., Luo, K., Li, Y., Li, X., Jia, X., Leon, C., (2010). Validation of the ITS2 Region as a Novel DNA Barcode for Identifying Medicinal Plant Species. PloS One, 5(1), e8613.

[26] Gao, T., Yao, H., Song, J., Liu, C., Zhu, Y., Ma, X., Pang X., Xu, H., \& Chen, S., (2010). Identification of Medicinal Plants in the Family Fabaceae Using a Potential DNA Barcode ITS2. Journal of Ethnopharmacology, 130(1), 116-121.

[27] Downie, S.R., Spalik, K., Katz-Downie, D.S., \& Reduron, J.P., (2010). Major Clades within Apiaceae Subfamily Apioideae as Inferred by Phylogenetic Analysis of nrDNA ITS Sequences. Plant Diversity and Evolution, 128(1-2), 111-136.

[28] Wang, Z.X., Downie, S.R., Tan, J.B., Liao, C.Y., Yu,Y., \& He, X.J., (2014). Molecular Phylogenetics of Pimpinella and Allied Genera (Apiaceae), with Emphasis on Chinese Native Species, Inferred From nrDNA ITS and cpDNA Intron Sequence Data. Nordic Journal of Botany, 32(5), 642-657.

[29] Nurcahyanti, A.D., Nasser, I.J., Sporer, F., Graf, J., Bermawie, N., Reichling, J., \& Wink, M., (2016). Chemical Composition of the Essential Oil From Aerial Parts of Javanian Pimpinella pruatjan Molk. and Its Molecular Phylogeny. Diversity, 8(3), 15.

[30] Wang, X.M., Hou, X.Q., Zhang, Y.Q., Yang, R., Feng, S. F., Li, Y., \& Ren, Y., (2012). Genetic Diversity of the Endemic and Medicinally Important Plant Rheum officinale as Revealed by Inter-Simpe Sequence Repeat (ISSR) Markers. International Journal of Molecular Sciences, 13(3), 3900-3915.

[31] Kakani, R.K., Singh, S.K., Pancholy, A., Meena, R.S., Pathak, R., \& Raturi, A., (2011). Assessment of Genetic Diversity in Trigonella foenum-graecum Based On Nuclear Ribosomal 
DNA, Internal Transcribed Spacer and RAPD Analysis. Plant Molecular Biology Reporter, 29(2), 315-323.

[32] Sindhu, A., Tehlan, S.K., \& Chaudhury, A., (2017). Analysis of Genetic Diversity Among Medicinal Therapist Trigonella foenum-graecum L. Genotypes Through RAPD and SSR Markers. Acta Physiologiae Plantarum, 39(4), 100.

[33] Kumar, S., Mahendi, H.A., Fougat, R.S., Sakure, A.A., \& Mistry, J.G., (2014). Transferability of Carrot (Daucus carota) Microsatellite Markers to Cumin (Cuminum cyminum). International Journal Seed Spices, 4(1), 88-90.

[34] Zhang, Y., Fan, C., Li, S., Chen, Y., Wang, R.R.C., Zhang, X., Han, F., \& Hu, Z., (2017). The diversity of Sequence and Chromosomal Distribution of New Transposable Element-Related Segments in the Rye Genome Revealed by FISH and Lineage Annotation. Frontiers in Plant Science, 8, 1706.
[35] Wallau, G.L., Ortiz, M.F., \& Loreto, E.L.S., (2012). Horizontal Transposon Transfer in Eukarya: Detection, Bias, and Perspectives. Genome Biology and Evolution, 4(8), 801-811.

[36] Sun, J., Yin, H., Li, L., Song, Y., Fan, L., Zhang, S., \& Wu, J., (2015). Evaluation of New IRAP Markers of Pear and Their Potential Application in Differentiating Bud Sports and Other Rosaceae Species. Tree Genetics \& Genomes, 11, 25.

[37] Zhang, M., Fan, L., Liu, Q., Song, Y., Wei, S., Zhang, S., \& Wu, J., (2013). A Novel Set of EST-Derived SSR Markers for Pear and Cross-Species Transferability in Rosaceae. Plant Molecular Biology Reporter, 32, 290-302.

[38] Liang, Y., Lenz, R.R., \& Dai, W., (2016). Development of Retrotransposon-Based Molecular Markers and Their Application in Genetic Mapping in Chokecherry (Prunus virginiana L.). Molecular Breeding, 36, 109. 